\title{
sciendo
}

\section{Investigations Regarding the Influence of Corporate Governance on Financial Performance. Empirical Study on Banks Listed on the Romanian Capital Market}

\author{
Tatiana Dănescu ${ }^{1}$, \\ Maria-Alexandra Popa ${ }^{1,2^{*}}$
}

${ }^{1}$ „, George Emil Palade” University of Medicine, Pharmacy, Science and Technology of Târgu-Mureș, 38 Gheorghe Marinescu, Târgu-Mures, 540139, Romania

2 ,1 Decembrie 1918” University of Alba Iulia, 5, Gabriel Bethlen, Alba Iulia, 510009, Romania

\begin{abstract}
The role of corporate governance in achieving the financial performance in a sustainable development context is recognized. A fundamental premise in defining and applying good corporate governance is the area of the elements that describe the structure of the capital, elements that influence the guidelines and policies of the Board of Directors regarding the obtaining of the financial performance. On the equation "share capital - financial performance" we find the imprint of the compliance rate of the management statements with the requirements of the Corporate Governance Code applicable on the capital market on which the entity trades its shares. In this context, considering the compliance of the management statements published in the set of annual reports with the Corporate Governance Code, our researches investigate the relationship between the capital structure and the financial performance of the banks listed on the Bucharest Stock Exchange.
\end{abstract}

Keywords: bank performance; corporate governance, corporate governance disclosure; panel data analysis, Bucharest Stock Exchange

\section{JEL Classification: G22, G34}

(C) 2019 Publised by ACTA MARISIENSIS, SERIA OECONOMICA, Publisher University Press Târgu Mureș, issued on behalf of University of Medicine, Pharmacy, Sciences and Technology "George Emil Palade" from Tîrgu Mureș, România

\footnotetext{
${ }^{*}$ Corresponding author: Maria-Alexandra Popa

e-mail: maria.popa@umfst.ro / maria.alexandra.popa@uab.ro
} 


\section{INTRODUCTION}

Banks are a strong pillar of the economy, which is why they must act in a transparent manner and support local and national economic development, responding to sustainable development goals. According to the reports of the National Bank of Romania, the dynamics of real GDP has evolved with the dynamics of real non-governmental credits. The banks listed on the Romanian capital market must meet the requirements imposed by the Bucharest Stock Exchange (BVB) and adopt a corporate governance that essentially guides the strategic management of the entities towards the expectations of all stakeholders (Dănescu \& Prozan, 2019; Dănescu \& Spătăcean, 2011), both those oriented towards financial performance and those aimed at increasing the transparency of financial reporting.

Based on those presented, we considered of interest the development of a research on the banks listed on the Bucharest Stock Exchange, which transact shares, regardless of the segment and category they belong to. The established coordinates led to the inclusion in the research of BRD - Groupe Societe Generale SA (BRD), Deutche Bank AG (DBK), Erste Group Bank AG (ERS), Patria Bank SA (PBK), Banca Transilvania SA (TLV). We mention that they were admitted to trading on different data, on different market segments (the situation is shown in Table 1). Considering the need for continuous financial performance needed for sustainable development, we oriented the research aim towards financial performance indicators, to determine whether they are positively influenced by the ownership structure of the social capital. In addition, the transparency requirements regarding the published financial information have guided our research efforts towards including in the area of investigations and the degree of compliance of the statements of the management - revealed in annual reports of the studied banks - with the Corporate Governance Code.

\section{DEFINING THE RESEARCHED MATTER}

\subsection{Banks financial performance}

For the expression of financial performance, we chose the return on assets (ROA) calculated as a ratio between net profit and total assets - and the return on equity (ROE) calculated as a ratio between net profit and equity.

We chose the two indicators to measure the ability of the selected entities to create the financial performance: the ROA indicator for evaluating the efficiency of the entire invested capital, while the ROE indicator for indicating the efficiency of the capital invested by the shareholders.

\subsection{Compliance rate with the Corporate Governance Code (CGC)}

Good corporate governance practices are meant to improve the financial performance of entities. With the declaration of a change in these practices (their improvement), the market can react positively, adding value to the reporting companies. (Imam, 2006). Over time, several researchers have studied the influence of the compliance of the management statements published in the annual report with the applicable Corporate Governance Code on the financial performance of banks, expressed through various indicators. For example, important studies have shown that good corporate governance positively influences the financial performance of companies (Lupu \& Nichitean, 2011; Renders et al., 2010; Cremers \& Ferrel, 2010; Johnson et al., 2009; Bebchuk el al.. 2009). Other studies have shown that even during the 2008 global crisis, proper corporate governance has positive effects on corporate performance. (Peni \& Vähämaa, 2012).

Similar to the study conducted by Samson \& Tarila (2014), we established two hypotheses regarding the relationship between the compliance rate and the financial performance: 


\title{
sciendo
}

\author{
ACTA MARISIENSIS, SERIA OECONOMICA \\ Online:ISSN 2668-3989, ISSN L 2668-3148 \\ Print:ISSN 2668-3148, ISSN L 2668-3148
}

Hypothesis 1a (H1a): There is a positive influence between the compliance rate of the management statements published in the annual report with the requirements expressed in the Corporate Governance Code and the ROA financial performance indicator.

Hypothesis $1 \mathrm{~b}(\mathrm{H} 1 \mathrm{~b})$ : There is a positive influence between the compliance rate of the management statements published in the annual report with the requirements expressed in the Corporate Governance Code and the ROE financial performance indicator.

\subsection{Capital Ownership}

Recent research regarding the influence of social capital structure on bank performance has highlighted the fact that there is a positive influence between the financial performance and the share of banks' share capital (Bajagai et al., 2019; Zhou et al., 2019; Erkens et al., 2010), while other researchers concluded that there is a negative influence between the financial performance and the share of banks' share capital (Fahlenbrach \& Stulz, 2011).

Carney et al. (2019) demonstrates a positive influence of the share of holdings in the share capital by foreign investors on the financial performance. Similar to the research carried out by Barako \& Tower (2007), we have elaborated two hypotheses regarding the influence on the financial performance of banks' holdings in the share capital by the members of the Board of Directors and by foreign investors:

Hypothesis 2a (H2a): The board ownership and foreign ownership positively influences the financial performance expressed by the ROA indicator.

Hypothesis $2 b(\mathrm{H} 2 \mathrm{~b})$ : The board ownership and foreign ownership positively influences the financial performance expressed by the ROE indicator.

\subsection{Data Description and Research Methodology}

\section{The Sample}

In the sample were selected banks listed on the capital market in the main segment or ATS. They have been admitted to trading on different dates and belong to different categories of segments. Table no. 1 briefly describes the profile of the banks identified on the website of the Bucharest Stock Exchange.

Table no. 1 - Banks profile

\begin{tabular}{|c|c|c|c|c|}
\hline $\begin{array}{c}\text { BSE } \\
\text { Symbol }\end{array}$ & Name of the bank & $\begin{array}{l}\text { Segment and } \\
\text { Category }\end{array}$ & $\begin{array}{c}\text { Start trading } \\
\text { date }\end{array}$ & Share number in 2018 \\
\hline BRD & $\begin{array}{c}\text { BRD - Groupe Societe } \\
\text { Generale S.A. }\end{array}$ & Principal, Premium & 15.01.2001 & 696.901 .518 \\
\hline DBK & Deutche Bank AG & ATS, INTL-ATS & 23.08 .2012 & 2.066 .773 .131 \\
\hline EBS & Erste Group Bank AG & Principal, INT'L & 14.02 .2008 & 429.800 .000 \\
\hline PBK & Patria BankS.A. & Principal Premium & 09.06 .2004 & 3.115 .330 .575 \\
\hline TLV & Banca Transilvania S.A. & Principal, Premium & 15.10 .1997 & 5.215.917.925 \\
\hline
\end{tabular}

For the banks selected in the sample we made observations regarding: a) the degree of compliance of the management statements published in the annual reports with the requirements of the Corporate Governance Code elaborated by the BSE, the degree of compliance established 
by analyzing the statement "Apply or explain" and calculated with the help of the scoring method (Spătăcean \& Ghiorghiță, 2012), expressed as a percentage; b) the ownership of the share capital and of the shareholder; c) financial performance indicators, expressed by ROA and ROE, recorded by the analyzed banks; d) the percentage of shares held by the members of the Board of Directors from the total of the shares.

Deutche Bank AG (DBK) is listed on the ATS market segment, in the INTL-ATS category, as it does not have to comply with the provisions of the Corporate Governance Code issued by BVB. Therefore, for DBK we could not identify information regarding the degree of compliance with the requirements of the Corporate Governance Code, as well as elements that reflect responsible social behavior, due to the lack of information on the BVB website. Therefore, this bank was not included in the hypothesis testing.

The investigations were carried out for a period of 8 years, during the period 2011-2018, on the annual reports found on the website of the Bucharest Stock Exchange, www.bvb.ro. The following were identified: the corporate governance statements that, according to the Corporate Governance Code, should be found as a separate heading in the annual report of the bank; shareholder information; financial information that refers to the size of the bank, as well as financial performance indicators.

\section{Dependent Variables}

The financial performance indicators selected as dependent variables are the return on assets (ROA) and return on equity (ROE). Table no. 2 contains a description of these indicators.

\section{Independent Variables}

The independent variables studied are related to the corporate governance requirements of the analyzed banks, as well as to the capital structure. In order to assess compliance with the requirements of the Corporate Governance Code, the procedure was as follows: 1 was associated when banks met the requirement, 0,5 when banks partially met the requirement, 0 when banks did not meet the requirement. Each requirement was given a degree of importance, thus calculating the compliance score of the banks with the requirements of the Corporate Governance Code of the BSE. This independent variable is rendered as CGDI and is expressed in percentages, which are obtained using the scoring method.

For the shareholding structure, the following independent variables were observed: holdings of shares in the share capital of the members of the Board of Directors - board ownership - (BOWN), foreign ownership (FOROWN) - identified as 1 if it is a majority foreign capital and with 0 , otherwise

Table 2 contains the description of the used variables.

Table no. 2 - Variable description

\begin{tabular}{|l|c|c|l|}
\hline \multicolumn{1}{|c|}{ Variable } & Acronym & Unit & Observation \\
\hline Dependent variables & ROA & $\%$ & $\begin{array}{l}\text { Financial performance indicator measured as a ratio } \\
\text { between net profit and total assets held. }\end{array}$ \\
\hline Return on assets & ROE & $\%$ & $\begin{array}{l}\text { Financial performance indicator measured as a ratio } \\
\text { between net profit and equity. }\end{array}$ \\
\hline Return on equity & \multicolumn{2}{|c|}{$\begin{array}{l}\text { The conformity rate evaluated was calculated as a } \\
\text { weighted average of the requirements implemented in } \\
\text { the Corporate Governance Code (1 when the } \\
\text { requirement is implemented, 0.5 when the requirement }\end{array}$} \\
\hline $\begin{array}{l}\text { Independent variables } \\
\text { Corporate Governance } \\
\text { compliance rate }\end{array}$ & CGDI & $\%$ &
\end{tabular}


ACTA MARISIENSIS, SERIA OECONOMICA

Online:ISSN 2668-3989, ISSN L 2668-3148

Print:ISSN 2668-3148, ISSN L 2668-3148

doi: $10.2478 /$ amso-2019-0004

\begin{tabular}{|l|l|c|l|}
\hline & & & $\begin{array}{l}\text { is partially implemented and 0 when the requirement } \\
\text { is not implemented) with the degree of importance } \\
\text { granted by the authors of each requirement. }\end{array}$ \\
\hline Board ownership & BOWN & $\%$ & $\begin{array}{l}\text { Calculated as a ratio between the number of shares } \\
\text { held by the members of the Board of Directors and the } \\
\text { total number of shares of the bank. }\end{array}$ \\
\hline Foreign ownership & FOROWN & 1,0 & $\begin{array}{l}\text { When more than } 50 \% \text { of the share capital is owned by } \\
\text { foreign investors - 1; otherwise } 0 .\end{array}$ \\
\hline
\end{tabular}

Source: The data were extracted from the annual reports of the analyzed banks, being accessible on the online platform of the Bucharest Stock Exchange http://www.bvb.ro. The calculations were performed by the authors.

\section{Econometric model}

In order to estimate the influence of the independent variables on the dependent variables (considered to measure the performance of the banks), the correlation matrix of the variables included in the study was prepared and the stationarity was tested. The data was found to be stationary. Thus, the Ordinary Least Square (OLS) model was applied to panel data, making a total of 32 observations, from 2011-2018. The OLS model is expressed in the following generalized form:

Where:

$$
y_{i t}=\beta_{0}+\beta_{1} X_{i t}+\varepsilon_{i t}
$$

$\mathrm{y}_{\mathrm{it}}=$ financial performance, expressed by ROA or ROE

$\beta=$ variable coefficient

$\mathrm{X}_{\mathrm{it}}=$ value of independent variable

$\varepsilon_{i t}=$ the error of the model, which shows the risk that the financial performance will be influenced by other factors that are not included in the econometric model.

Additional tests specific to panel type models have been applied to determine which model is appropriate.

\section{RESULTS}

The correlation matrix of both dependent and independent variables was determined. The results are presented in Table no. 3 .

Table no. 3 - Correlation matrix

\begin{tabular}{|c|c|c|c|c|c|}
\hline & ROA & ROE & CGDI & BOWN & FOROWN \\
\hline ROA & 1 & & & & \\
\hline ROE & 0.97 & 1 & & & \\
\hline CGDI & 0.43 & 0.38 & 1 & & \\
\hline BOWN & 0.49 & 0.48 & 0.80 & 1 & \\
\hline FOROWN & 0.58 & 0.65 & 0.20 & 0.36 & 1 \\
\hline
\end{tabular}

Source: authors 'research and projection 
We note that there is a positive correlation of high intensity between the board ownership and the compliance rate. Therefore, we will not include these variables in the model simultaneously.

Applying the Hausman test, we found that the p-value is greater than 0.05 , which means that the model suitable for our data is the one with random effects. The results presented in Table no. 4 are obtained by applying random effects. These effects indicate that events are timedependent, with banks having no similar characteristics. Changes in the presentation of errors occur in all banks, in certain years. The phenomenon can be explained by the macroeconomic factors that influence the activity in the banking sector at national or international level during a reporting year. Thus, the entire sample is affected by events over the same time period.

Table no. 4 - OLS regression results

\begin{tabular}{|c|c|c|c|c|}
\hline & Model 1 & Model 2 & Model 3 & Model 4 \\
\hline \multicolumn{5}{|l|}{ Dependent variables } \\
\hline ROA & $\mathrm{x}$ & & $\mathrm{x}$ & \\
\hline ROE & & $\mathrm{x}$ & & $\mathrm{x}$ \\
\hline \multicolumn{5}{|c|}{ Independent variables } \\
\hline CGDI & $0.087^{*}$ & 0.55 & - & - \\
\hline BOWN & - & - & $0.29^{* *}$ & $2.54^{*}$ \\
\hline FOROWN & - & - & $0.01^{* * *}$ & $0.22^{* * *}$ \\
\hline $\mathrm{R}^{2}$ & 0.09 & 0.04 & 0.41 & 0.50 \\
\hline Adjusted- $\mathrm{R}^{2}$ & 0.06 & 0.01 & 0.37 & 0.46 \\
\hline F sign. & 0.0484 & 0.2417 & 0.0004 & $<0.0001$ \\
\hline
\end{tabular}

Although the results of Model 1 in Table 4 show us a statistically significant positive influence between the degree of compliance and the ROA indicator, due to the low value recorded by $\mathrm{R}^{2}$, we consider that to determine the influence on the financial performance, expressed by the ROA indicator, of the degree of compliance with the requirements of the Corporate Governance Code it is necessary to include in research and other influencing factors.

The compliance rate of the banks with the requirements of the Corporate Governance Code does not statistically significantly influence the ROE financial performance indicator (Model 2). The results indicate that to establish an influence on the compliance rate with the requirements of the Corporate Governance Code, as an independent variable, on how banks manage their assets for profit, it would be necessary to extend the research and include it in the research and of other influencing factors. We consider that the ownership structure as an independent variable can affect the degree of compliance, but also the financial performance, which is why the research in this regard was continued.

The influence of foreign capital on banks' performance (expressed by ROA and ROE), from Model 3 and 4, is a positive and statistically significant one, according to the models applied resulting in banks having share capital belonging to the members of the Board of Directors and which majority shareholding with foreign ownership tend to register an increase in financial performance. 


\section{sciendo}

ACTA MARISIENSIS, SERIA OECONOMICA

Online:ISSN 2668-3989, ISSN L 2668-3148

Print:ISSN 2668-3148, ISSN L 2668-3148

Table no. 5 - Research Hypothesis status

\begin{tabular}{|c|c|c|}
\hline Hypothesis & Accepted / Rejected & Observations \\
\hline H1a & Rejected & $\begin{array}{c}\text { The results obtained by the low value registered by R } \mathrm{R}^{2} \text { do not show the } \\
\text { impairment of the financial performance expressed by ROA of compliance rate } \\
\text { with the requirements of the Corporate Governance Code. }\end{array}$ \\
\hline $\mathrm{H} 1 \mathrm{~b}$ & Rejected & $\begin{array}{c}\text { The obtained results do not show a statistically significant influence of the } \\
\text { compliance rate with the requirements of the Corporate Governance Code on } \\
\text { the financial performance expressed by ROE. }\end{array}$ \\
\hline $\mathrm{H} 2 \mathrm{a}$ & Accepted & $\begin{array}{c}\text { The obtained results show that there is a statistically significant positive } \\
\text { influence on the ROA indicator of the board ownership and of the predominant } \\
\text { existence of foreign capital in the share capital. }\end{array}$ \\
\hline $\mathrm{H} 2 \mathrm{~b}$ & Accepted & $\begin{array}{c}\text { The obtained results show that there is a statistically significant positive } \\
\text { influence on the ROE indicator of the board ownership and of the predominant } \\
\text { existence of foreign capital in the share capital. }\end{array}$ \\
\hline
\end{tabular}

Source: authors`research and projection

\section{CONCLUSIONS}

Bank performance, when expressed by ROA and ROE financial indicators, is influenced by the ownership rights of the management, as well as by foreign ownership. Through the results that demonstrate the acceptance of $\mathrm{H} 2 \mathrm{a}$ and $\mathrm{H} 2 \mathrm{~b}$, the influence on the financial performance of the share capital structure is positive if the members of the Board of Directors own shares and if the shares are owned by foreign investors.

On the other hand, by testing the hypotheses $\mathrm{H} 1 \mathrm{a}$ and $\mathrm{H} 1 \mathrm{~b}$, the obtained results did not show that the financial performance affected the compliance rate with the requirements of the Corporate Governance Code.

In the context of applying the study for banks operating on the Romanian capital market (a small number of banks), but also due to the lack of financial information from the site of the banks selected in the sample or from the website of the Bucharest Stock Exchange, we consider that the model was applied on a limited data set, which does not allow us to generalize the obtained results. However, this will be a prerequisite for future research directions, and will be extended to a larger sample of banks operating in Romania, regardless of the market they operate, but also in other countries.

\section{ACKNOWLEDGEMENT}

This work is part of the Development of tertiary education in support of economic growth-PROGRESSION, project code POCU / 380/6/13/125040, project co-financed by the European Social Fund through the Human Capital Operational Program 2014-2020.

\section{Bibliography:}

Bajagai R.K., Keshari R.K., Bhetwal P., Sah R.S. \& Jha R.N. (2019) Impact of Ownership Structure and Corporate Governance on Capital Structure of Nepalese Listed Companies. In: Rajagopal, Behl R. (eds) Business Governance and Society. Palgrave Macmillan, Cham, 2019. 
Barako, D.G. \& Tower, G. (2007). Corporate Governance and Bank Performance: Does Ownership Matter? Evidence from Kenyan Banking Sector. Corporate Ownership \& Control, Vol. 4, Issue 2, pp. 133-144.

Bebchuk, L., Cohen, A. \& Ferrell, A. (2009) What matters in corporate governance? Rev Financ Stud 22, pp. 783-827.

Carney, M., Estrin, S.; Liang, Z. \& Shapiro, D. (2019). National institutional systems, foreign ownership and firm performance: The case of understudied countries. Journal of World Business, Vol. 54, Issue 4, pp. 244-257, https://doi.org/10.1016/j.jwb.2018.03.003 .

Cremers, K. \& Ferrell, A. (2010) .Thirty years of corporate governance: Firm valuation \& stock returns. Working paper, Yale School of Management and Harvard Law School

Dănescu, T., Prozan, M. (2019). Valences of the Corporate Governance in the Process of Accounting Reporting. in: Throughput Accounting in a Hyperconnected World, IGI Global, http://doi.org/10.4018/978-1-5225-7712-6.ch007.

Dănescu, T., Spătăcean, O. (2011). Assesing compliance with corporate governance principles in case of Romanian Financial Investment Companies, Annales Universitatis Apulensis Series Oeconomica, Numarul 13 (Volumul 2), p. 363.

Erkens, D., Hung, M, Matos, P. (2010) Corporate governance in the 2007-2008 financial crisis: Evidence from financial institutions worldwide. Working paper, University of Southern California.

Fahlenbrach, R., Stulz, R. (2011) Bank CEO incentives and the credit crisis. J Financ Econ, Vol. 99, pp. 11-26.

Imam, M.O. (2006). Firm Performance and Corporate Governance through Ownership Structure: Evidence from Bangladesh Stock Market. Paper presented in 2006 ICMAB Conference.

Johnson, S., Moorman, T., Sorescu, S. (2009) A reexamination of corporate governance and equity prices. Rev Financ Stud 22, pp. 4753-4786.

Lupu, D., Nichitean, A. (2011). Corporate Governance and Bank Performance în Romanian Banking Sector. The Annals of the "Stefan cel Mare" University of Suceava. Fascicle of The Faculty of Economics and Public Administration, vol. 11, issue 1(13), pp. 219-225.

Peni, E., Vähämaa, S. (2012). Did Good Corporate Governance Improve Bank Performance during the Financial Crisis?. J Financ Serv Res 41, pp. 19-35, http://doi.org/10.1007/s10693-0110108-9.

Renders, A., Gaeremynck, A., Sercu, P. (2010) Corporate-governance ratings and company performance: a cross-European study. Corp Gov: Int Rev 18, pp. 87-106.

Samson, O., Tarila, B. (2014). Corporate Governance and Financial Performance of Banks: Evidence from Nigeria. Acta Universitatis Danubius. Economica, Vol 10, No 2, pp. 216-230.

Spătăcean, O., Ghiorghiță, L. (2011). Testing Compliance with Corporate Governance Principles on the Romanian Capital Market. Studia Universitatis Petru Maior, Series Oeconomica, Fasciculus 1, anul VI, pp. 70-85.

Zhou, F., Fu, Y., An, Y., Yang, J. (2018). Impacts of Ownership Balance and Nonexecutive Directors on Bank Performance and Risk Taking: Evidence from City Commercial Banks in China. Global Economic Review, 1-24. http://doi.org/10.1080/1226508x.2018.1528170. 